\title{
A MODERNA FILOSOFIA ALEMÃ COMO HERDEIRA DA REFORMA PROTESTANTE: UMA INVESTIGAÇÃO A PARTIR DE HEINE
}

Marcio Gimenes de Paula ${ }^{1}$

\section{Resumo:}

O objetivo do presente artigo é investigar a origem protestante da moderna filosofia alemã. Para atingir tal intuito nos delimitaremos a uma análise da instigante obra de Heine, a saber, Contribuição à história da religião e da filosofia na Alemanha. Julgamos que nela se expressa com contundência a herança protestante da moderna filosofia alemã e, desse modo, almejamos fazer sua avaliação.

Palavras-chave: Cristianismo. Filosofia Contemporânea. Filosofia da Religião. Heine.

\section{THE MODERN GERMAN PHILOSOPHY AS HEIRESS TO THE PROTESTANT REFORMATION: AN INVESTIGATION FROM HEINE}

\begin{abstract}
:
The aim of this article is to investigate the Protestant origin of modern German philosophy. To achieve this, we will delimit an analysis of Heine's instigating work, namely Contribution to the History of Religion and Philosophy in Germany. We believe that the Protestant heritage of modern German philosophy is strongly expressed in it, and so we aim to make its assessment.
\end{abstract}

Key words: Christianity. Contemporary Philosophy. Philosophy of Religion. Heine.

\section{Introdução}

Muitas reflexões e trabalhos investigativos já foram feitos sobre a influência do pensamento religioso, notadamente do pensamento protestante, sobre a moderna filosofia alemã². A visão, talvez mais clássica é aquela apresentada por Hegel nas suas Lições da Filosofia da História ${ }^{3}$ e, de algum modo, recuperada por Karl Löwith no seu De Hegel a Nietzsche $e^{4}$ Tal caracterização pode ser facilmente observável se nos

1 Possui graduação em filosofia pela Universidade Estadual de Campinas (1999), graduação em teologia pelo Seminário Teológico Presbiteriano Independente (1994), mestrado em Filosofia pela Universidade Estadual de Campinas (2002) e doutorado em Filosofia pela Universidade Estadual de Campinas (2005). Atualmente é professor adjunto IV do departamento de Filosofia da Universidade de Brasília. E-mail: marciogimenes@unb.br

2 Uma obra exemplar é a de FERNÁNDEZ, Arsenio Ginzo. Protestantismo y filosofia - la recepción de la Reforma em la filosofia alemana. Alcalá: Universidad de Alcalá, 2000.

3 HEGEL, G.W.F. Lecciones sobre la filosofía de la historia universal. Madrid: Alianza Editorial, 1984.

4 LÖWITH, K. De Hegel à Nietzsche. São Paulo: UNESP, 2014. 
dispusermos a estudar qualquer um dos assim chamados pensadores pós-hegelianos. Neles a influência da religião e seu trânsito entre a política e a literatura são mais do que observáveis, são fundamentais para o seu próprio fazer filosófico. Por isso, optamos aqui por voltar mais firmemente nossas reflexões no intuito de investigar essa mesma temática através de um prisma ainda pouco utilizado pelos filósofos: a obra História da Religião e da Filosofia na Alemanha de Heinrich Heine (1797-1856).

A obra de Heine é composta de um preâmbulo e de três livros. O primeiro deles abordará Lutero e suas consequências para a filosofia alemã, o segundo livro disserta mais efetivamente sobre a filosofia alemã. Todavia, nunca se pode esquecer que tal tipo de explicação, notadamente na filosofia alemã, nunca consegue ser feita em separado da religião. Heine aborda aqui oito pensadores: Descartes (visto como o mais alemão dos filósofos franceses), Leibniz, Wolff, Espinosa (que também não é alemão), Jacobi, Paracelso, Jacob Bohme e Lessing. Além deles, surgem referências a Kant, Schelling, Hegel e Fichte, que serão analisados cuidadosamente no terceiro livro. Tratase, evidentemente, de uma espécie de panorama da história da filosofia alemã e, como todo panorama, não consegue apresentar a totalidade e sequer almeja fazer isso. Todavia, com extrema ironia e perspicácia, Heine consegue esboçar um primeiro esforço em compreender diversos temas importantes do pensamento germânico. Feitos tais esclarecimentos, passemos, portanto, a uma exposição pormenorizada da obra citada, operando um diálogo da mesma com outros filósofos da tradição moderna germânica.

Heinrich Heine, célebre poeta e escritor alemão publica, no ano de 1834, uma obra intitulada Contribuição à história da religião e da filosofia na Alemanha. Seu principal intuito é lançar uma resposta à obra De L'Allemagne de Mme. Staël ${ }^{5}$, cujo texto caracteriza-se por demonstrar uma visão majestosa da história do pensamento germânico. Desse modo, fica muito evidente aqui o objetivo do escritor alemão: ser lido pelo público francês e explicitar a ele um pouco da história do pensamento alemão. Por isso é que, de forma absolutamente planejada, a obra é destinada a tal público e surge, originalmente, em revistas francesas.

Segundo Heine, uma interpretação original da história do pensamento alemão deve principiar com a Reforma Protestante e ir até o advento da moderna filosofia alemã. Trata-se, portanto, de um movimento teológico-filosófico equivalente a

\footnotetext{
${ }^{5}$ Recentemente traduzido no Brasil: MADAME DE STÃEL. Da Alemanha. São Paulo: UNESP, 2016.
}

\begin{tabular}{|l|l|l|l|l|}
\hline Q Povista Qialectus & Ano 5 & n. 12 & Janeiro - Julho 2018 & p. 241-264 \\
\hline
\end{tabular}


Revolução Francesa. Somente se tivermos tal coisa em mente é que compreenderemos a verdadeira essência da filosofia alemã. A obra de Heine possui dois prefácios: o primeiro, de 1834, traz poucas informações sobre o todo da obra; já o segundo, de 1852, traz maiores informações e mostra claramente o quanto o autor articula uma estratégia irônica para escapar da censura e de eventuais ataques por contrariar algumas posições religiosas. Por isso, ele afirma que mentiu em todas as informações religiosas que forneceu no decorrer do seu texto:

A um homem probo, no entanto, resta em qualquer circunstância o direito
inalienável de admitir abertamente seu erro, e desejo aqui exercê-lo sem
nenhum receio. Por isso, confesso com franqueza que tudo o que neste livro
se refere particularmente às questões religiosas é tão impensado quanto falso.
Tão impensada quanto falsa é a afirmação escolar, por mim repetida, de que
o deísmo está demolido na teoria e só penosamente ainda resiste no mundo
dos fenômenos. Não é verdade que a crítica da razão, que destruiu as novas
provas da existência de Deus, tais como as conhecemos desde Anselmo de
Cantuária, também pôs fim à própria existência de Deus. O deísmo vive, vive
sua vida mais viva; não está morto, e muito menos o matou a moderna
filosofia alemã. A dialética de teia de aranha de Berlim não é capaz de atrair
um cão, nem matar um gato e muito menos um Deus (Heine, 1991, p. 14-15).

Hegel surge aqui, mais do que como a teia de aranha de Berlim, mas como o pensador que introduzirá, notadamente na sua Fenomenologia do espírito, o célebre e complexo conceito de consciência de si. Todavia, o que aqui interessa para Heine é apenas apontar que, no suposto Jardim do Éden, a serpente e suas propostas de sabedoria já preconizaram em pelos menos seis mil anos antes tudo aquilo que o célebre professor proporia no futuro. Por isso, de forma absolutamente jocosa, ele compara a consciência de si em Eva como um desejo de comprar belos vestidos:

Logo no início, a história da árvore proibida e da serpente do Paraíso, a pequena livre-docente que já expôs toda a filosofia hegeliana seis mil anos antes do nascimento de Hegel. De maneira bem perspicaz, essa pedante sem pés mostra como o Absoluto consiste na identidade de ser e saber, como o homem se torna Deus por intermédio do conhecimento, ou, o que vem a der no mesmo, como Deus chega à consciência de si no homem. - Esta última fórmula não é tão clara quanto as palavras originais: 'Se provardes da árvore do conhecimento, sereis como Deus!' De toda a demonstração, dona Eva reteve apenas uma coisa: que o fruto era proibido e, porque era proibido, a boa senhora o provou. Mal, porém, mordeu a apetitosa maçã perdeu a inocência, a imediatez ingênua e, achando-se demasiado despida para uma pessoa na condição de mãe ancestral de tantos futuros imperadores e reis, exigiu um vestido. Por certo, apenas um vestido de folhas de figueira, pois ainda não haviam nascido os fabricantes de seda de Lyon e ainda não existiam chapeleiras e modistas no Paraíso... (Heine, 1991, p. 16).

\begin{tabular}{|l|l|l|l|l|}
\hline Q Rovista Dialectus & Ano 5 & n. 12 & Janeiro - Julho 2018 & p. 241-264 \\
\hline
\end{tabular}


Tais observações espirituosas, fornecem o tom da obra de Heine. Seu intuito, tal como anuncia o título de sua obra, é tratar da temática da religião e da filosofia na Alemanha. Entretanto, além da estratégia irônica prévia de defesa, ele lança aqui um novo apelo para as almas pias. A despeito de não ter nunca experimentado ou vivenciado um milagre, ele almeja trazer algumas contribuições para as discussões acerca do pensamento alemão e suas origens:

\begin{abstract}
Almas pias parecem sequiosas de que lhes impinja um milagre qualquer e de bom grado gostariam de saber se não vi, como Saulo, a luz no caminho de Damasco ou se não cavalguei, com Balaão, o filho de Beor, numa mula recalcitrante, que de repente abriu a boca e começou a falar como um homem: ó almas crédulas! Jamais viajei para Damasco, nada sei sobre Damasco... Também jamais vi uma mula, isto é, uma mula quadrúpede que falasse como um homem, mas já encontrei muitos homens que, toda vez que abriam a boca, falavam como mulas (Heine, 1991, p. 16-17).
\end{abstract}

Não interessa para Heine nenhum tipo de iluminação fantástica. Ele, na condição de um típico alemão, apenas advoga em seu favor o fato de ter sido formado dentro do espectro cultural fornecido pela Reforma Protestante e de ter recebido o apreço que a mesma possui pelas Escrituras:

\begin{abstract}
Na verdade, nem uma visão, nem um seráfico arrebatamento, nem uma voz celestial, nem ainda um sonho notável ou uma aparição maravilhosa que pôs a caminho da salvação, e devo minha iluminação muito simplesmente à leitura de um livro. - De um livro? Sim, e um simples livro antigo, singelo como a natureza, e também natural como ela; um livro do dia-a-dia, despretensioso como o sol que me aquece, como o pão que nos alimenta; um livro que nos fita com tanta intimidade, com tanta bênção, com tanta benevolência quanto a velha avó que o lê diariamente com lábios amáveis, trêmulos, e óculos na ponta do nariz - , e esse livro se chama bem sucintamente o Livro, a Bíblia (Heine, 1991, p. 17).
\end{abstract}

\title{
1. O primeiro livro de Contribuição à história da religião e da filosofia na Alemanha
}

O objeto de análise do primeiro livro da obra de Heine será Lutero e a Reforma. Para o pensador alemão, os franceses se equivocam ao tentar compreender a Alemanha por intermédio da sua literatura. A chave para sua compreensão se encontra na religião e, posteriormente, no seu desdobramento que é a filosofia. Desse modo, para

\begin{tabular}{|l|l|l|l|l|}
\hline Q Rovista Dialectus & Ano 5 & n. 12 & Janeiro - Julho 2018 & p. 241-264 \\
\hline
\end{tabular}


que o pensamento alemão seja compreendido é necessário que se esclareça tanto a sua religião como a sua filosofia. Todavia, Heine confessa que não é um erudito. Este seria o seu limite. Entretanto, é, ao mesmo tempo, sua vantagem, uma vez que tal grupo não parece disposto, no entender do autor, em dividir o seu conhecimento com aqueles que dele necessitam:

\begin{abstract}
Grandes filósofos alemães, que por acaso corram os olhos nestas páginas, darão sobranceiramente de ombros para o mísero traje de tudo aquilo que apresento aqui. Mas que façam o obséquio de considerar que o pouco que digo é expresso de modo bem claro e distinto, ao passo que, por mais profundas, imensuravelmente profundas, e por mais penetrantes, estupendamente penetrantes, que sejam suas obras, são, ainda assim, incompreensíveis. De que servem os celeiros fechados, se o povo não lhes tem as chaves? O povo tem fome de saber e me agradece o pequeno pedaço de pão espiritual que com ele honestamente partilho. Não creio ser falta de talento o que impede a maioria dos eruditos alemães de discorrer de forma popular sobre religião e filosofia. Creio ser receio dos resultados de seu próprio pensar, resultados que não ousam transmitir ao povo. Quanto a mim, não tenho esse receio; pois não sou erudito, sou povo. Não sou erudito, não faço parte dos setecentos sábios da Alemanha. Deixo-me ficar com a multidão diante das portas de sua sabedoria, e se alguma verdade escapa por entre elas e chega até mim, já foi bastante longe: com belas letras a escrevo no papel e a entrego ao tipógrafo, que a compõe em chumbo e a passa ao impressor, que a imprime e, então, ela pertence a todo o mundo (Heine, 1991, p. 19-20).
\end{abstract}

Com efeito, o estudo do pensamento alemão deve principiar com o estudo da religião na Alemanha. Primeiramente deve-se estudar o cristianismo, depois sua passagem para o catolicismo, depois ainda sua passagem ao protestantismo e como, a partir desse, surge a filosofia alemã. Por isso, Heine é absolutamente enfático e claro em sua divisão cronológica: "O cristianismo é a religião que temos desfrutado na Alemanha. Terei, portanto, de contar o que é o cristianismo, como se tornou catolicismo romano, como deste surgiu o protestantismo e como do protestantismo surgiu a filosofia alemã" (Heine, 1991, p. 20).

Novamente, de forma irônica, Heine pede perdão às almas piedosas e, tal como Feuerbach o faz na Essência do cristianismo ${ }^{6}$, aponta que a essência do cristianismo reside numa ideia. Desse modo, mesmo toda a crítica de autores como Voltaire nada mais conseguiram fazer do que atingir o corpo já debilitado do cristianismo. Todavia, não foram capazes de ferir a sua essência, que reside numa ideia e, por isso, como bem sabia Feuerbach, possui uma força:

\footnotetext{
${ }^{6}$ FEUERBACH, L. A essência do cristianismo. Petrópolis: Vozes, 2009.

\begin{tabular}{|l|l|l|l|l|}
\hline Q Rovista 2 Dialectus & Ano 5 & n. 12 & Janeiro - Julho 2018 & p. 241-264 \\
\hline
\end{tabular}
}


Voltaire pôde ferir apenas o corpo do cristianismo. Todos os seus gracejos tirados da história eclesiástica; todos os seus chistes sobre a dogmática e o culto; sobre a Bíblia, o livro mais sagrado da humanidade; sobre a Virgem Maria, a mais bela flor da poesia; todo o Dictionnaire de flechas filosóficas que disparou contra clero e confraria, feriram apenas o corpo agonizante do cristianismo, não a sua essência íntima, o seu espírito mais profundo, a sua alma eterna (Heine, 1991, p. 20-21).

No entender de Heine, não há uma história clara do cristianismo. Nela, dois partidos estão sempre em luta: no primeiro momento, surge o cisma entre a Igreja do Ocidente, marcada pela cultura romana, e a Igreja do Oriente, marcada pela cultura grega; num segundo momento, afirma-se um cisma no próprio Ocidente, isto é, uma polêmica entre católicos e protestantes. Desse modo, o pensador alemão sugere que, até o momento a história do cristianismo não passou de um estudo de superficialidades e de interesses: "Ainda não há nenhuma história do cristianismo justamente porque ainda não se compreendeu claramente essa ideia e porque superficialidades foram tomadas pelo essencial" (Heine, 1991, p. 21).

Sua proposta é realizar uma pré-história do cristianismo, isto é, começar pela análise da questão dos maniqueus e dos gnósticos. Segundo ele, os primeiros se caracterizam por afirmarem a crença num eterno combate entre o bem e o mal; já o segundo grupo, se caracterizaria por afirmar uma espécie de pré-existência do bem:

\footnotetext{
Os maniqueus receberam essa doutrina da antiga religião persa, na qual Auramasda, a luz, é hostilmente oposta a Arimã, as trevas. Os gnósticos propriamente ditos acreditavam antes na preexistência do princípio do Bem e explicavam o surgimento do princípio do Mal pela emanação, pelas gerações de eões que se deterioram e se turvam quanto mais distantes estejam da origem (Heine, 1991, p. 22-23).
}

Aqui encontramos o cerne da argumentação de Heine na sua explicação do cristianismo. Para ele, a despeito da vitória do grupo gnóstico nos debates, o cristianismo ainda adquiriu resquícios da proposta maniqueísta. Tal perspectiva faz uma clara oposição entre espírito e natureza. Desse modo, boa parte daquilo que a humanidade conhecia por natureza se perde ou é explicitamente rejeitado nessa estranha conjunção:

De origem hindu, essa visão de mundo gnóstica trazia implícita a doutrina da encarnação de Deus, do perecimento da carne, da introspecção espiritual, e

\begin{tabular}{|c|c|c|c|c|}
\hline Revista Dialectus & Ano 5 & n. 12 & Janeiro - Julho 2018 & p. $241-264$ \\
\hline
\end{tabular}


gerou a vida monástica de contemplação ascética, a mais pura flor da ideia cristã. No dogma, tal ideia só pôde ser expressa de uma maneira bastante confusa e, no culto, de uma maneira bastante obscura. Não obstante, em toda a parte vemos surgir a doutrina dos dois princípios: ao bom Cristo, que representa o mundo do espírito, se opõe o maligno Satanás, que representa o mundo da matéria; àquele pertence nossa alma, a este nosso corpo; e assim, todo o mundo dos fenômenos- a natureza- é originalmente mau, e Satanás, o príncipe das trevas, deseja nos levar à perdição, sendo necessário renunciar a todos os prazeres sensíveis da vida e flagelar o corpo, o feudo de Satanás, para que a alma se eleve tanto mais esplendidamente ao céu luminoso, ao resplandecente reino de Cristo (Heine, 1991, p.23).

Desse modo, antecipando algumas das teses de Feuerbach na Essência do cristianismo (1841), de Nietzsche no Anticristo $^{7}$ (1887) e de Freud no Futuro de uma ilusão ${ }^{8}$ (1927), Heine afirma categoricamente que o cristianismo se propaga tal como uma doença, debilitando todo o Ocidente:

De uma maneira espantosamente rápida, essa visão do mundo, a verdadeira ideia do cristianismo, se propagou por todo o Império Romano como uma doença contagiosa; os sofrimentos se prolongaram por toda a Idade Média, ora como acesso de febre, ora como prostração, e nós modernos, ainda sentimos cãibras e fraquezas nos membros (Heine, 1991, p. 23).

Todavia, Heine, dentro do melhor espírito iluminista, parece esperançoso em superar tal religião de sofrimento e legar aos seus futuros descendentes algo melhor:

\begin{abstract}
Quando a humanidade recobrar sua plena saúde, quando a paz entre corpo e alma for restabelecida e novamente se unirem em sua harmonia original, mal se poderá compreender a artificial discórdia que o cristianismo semeou entre ambos. As gerações mais felizes e belas que, engendradas pelo amor livre, florescerão numa religião de alegria, sorrirão, melancólicas, de seus pobres antepassados, que lugubremente se abstiveram de todos os gozos desta bela terra e quase desapareceram, como frios espectros, pela mortificação de sua viva e ardente sensualidade. Afirmo com certeza que nossos descendentes serão mais felizes e belos do que nós. Pois acredito no progresso, acredito que a humanidade esteja destinada à felicidade e, por isso, tenho sobre a divindade uma opinião mais favorável do que essa gente pia, que presume que criou o homem apenas para o sofrimento (Heine, 1991, p. 23-24).
\end{abstract}

Sua esperança possui ainda uma conotação política. Por isso, não fortuitamente, Heine aponta aqui, com forte ironia, alguns aspectos de como a religião pode ser utilizada pelos poderosos para a dominação dos pobres. Com efeito, ele

\footnotetext{
${ }^{7}$ NIETZSCHE, F. O Anticristo. São Paulo: Companhia das Letras, 2007.

${ }^{8}$ FREUD, S. O futuro de uma ilusão. Porto Alegre: LPM, 2010.

\begin{tabular}{|c|c|c|c|c|}
\hline Q Rovista Dialectus & Ano 5 & n. 12 & Janeiro - Julho 2018 & p. 241-264 \\
\hline
\end{tabular}
}


antecipa aqui alguns aspectos da crítica que Marx, baseando-se em Feuerbach, realizará da religião enquanto ideologia e instrumento repressivo:

Talvez porque estejam seguros de seu poder e talvez porque, para infelicidade nossa, decidiram em segredo abusar eternamente dele, os grandes deste mundo estão convencidos da necessidade do cristianismo para seus povos e, no fundo, é um terno sentimento humanitário que os faz despender tanto esforço para a conservação dessa religião!

O destino final do cristianismo dependerá, pois, de se ainda precisaremos dele. Por dezoito séculos, essa religião foi um reconforto para a humanidade sofredora: foi providencial, divina, sagrada. Tudo o que fez em benefício da civilização, amansando os fortes e fortalecendo os fracos, unificando os povos pelo mesmo sentimento e idioma, e tudo o mais que possa ser enaltecido por seus apologistas é ainda insignificante em comparação com o grande consolo que, por si mesma, proporcionou aos homens (Heine, 1991, p. 24).

No entender de Heine, a Igreja, durante toda a Idade Média, zelou pela ideia do bem em toda a cristandade europeia mantendo, desse modo, uma certa unidade na compreensão do bem. Contudo, o mesmo não ocorreu em relação a ideia de mal, que se apresentou de forma variada e diversificada. Um exemplo cabal disso é que na Alemanha a ideia de mal é bastante diferente das concepções mais latinas. Para o pensador alemão, tal coisa ocorre em virtude do cristianismo nunca ter rejeitado totalmente as divindades nacionais:

\footnotetext{
Mas sobre o princípio do Mal, sobre o império de Satã, reinavam opiniões diferentes nos diversos países, e a seu respeito se tinham, no norte germânico, ideias totalmente distintas das do sul romântico. Isso se devia ao fato de que o clero cristão não rejeitava, como vãs quimeras, os antigos deuses nacionais que encontrou, mas admitia-lhes uma existência real, afirmando, porém, que todos esses deuses não passavam de diabos e diabas que perderam o poder sobre os homens com a vitória de Cristo, e agora queriam desviar para o pecado através da volúpia e da astúcia. Todo o Olimpo se tornou um inferno etéreo, e por mais formosamente que o poeta da Idade Média cantasse os mitos gregos, o cristão pio via neles apenas assombrações e demônios. O lúgubre delírio dos monges atingiu mais duramente a pobre Vênus, que passava por uma filha de Belzebu... (Heine, 1991, p. 26).
}

O norte germânico era panteísta, isto é, lá se acreditava plenamente que Deus e a natureza formavam um todo integral, sem distinções. Com a chegada do cristianismo, tal posição se altera e a natureza é demonizada, prevalecendo o divino sobre a natureza, isto é, a cisão. Por isso, para Heine, o cristianismo nórdico é esteticamente pior se comparado ao cristianismo romano do sul, que se caracteriza pelo

\begin{tabular}{|l|l|l|l|l|}
\hline Q Rovista Dialectus & Ano 5 & n. 12 & Janeiro - Julho 2018 & p. 241-264 \\
\hline
\end{tabular}


refinado gosto estético oriundo das belezas da civilização greco-romana e de uma relação mais saudável e equilibrada com a natureza, mesmo depois do advento do cristianismo. Para o leitor francês não é uma tarefa fácil compreender o gosto germânico pelos diabos e pelo horror. Tais dados, já observados aqui por Heine, serão fartamente explorados futuramente. No século XX, por exemplo, Walter Benjamin realiza, na sua célebre tese $A$ origem do drama trágico alemão ${ }^{9}$, uma instigante análise do fascínio que os alemães possuíam pelas histórias de terror. Tais histórias se constituíram num importante apoio para um tipo de divulgação que almejava, através de apresentações públicas, infundir o medo nas pessoas estimulando-as, desse modo, a uma vida devota e consagrada aos assuntos divinos. Desse modo, nem mesmo a Reforma de Lutero foi capaz de romper com esse tipo de cristianismo nórdico e sua visão panteísta:

Tais atrocidades não eram provocadas diretamente pela Igreja cristã, mas indiretamente, já que havia tão perfidamente desfigurado a antiga religião nacional germânica, transformando a visão de mundo panteísta dos alemães em uma visão de mundo pandemônica e convertendo em vil feitiçaria os antigos santuários do povo. O homem, porém, não renuncia de bom grado àquilo que foi precioso e caro para si mesmo e seus antepassados, e secretamente seus sentimentos a isso se agarram com firmeza, mesmo que já o tenham corrompido e deformado. Eis por que essa desfigurada crença popular talvez ainda se sustente na Alemanha por mais tempo do que o cristianismo, que, diferentemente dela, não se enraíza na nacionalidade. $\mathrm{Na}$ época da Reforma, desapareceu muito rapidamente a crença nas lendas católicas, mas de maneira alguma a crença na magia e bruxaria.

Lutero já não acredita em milagres católicos, mas ainda acredita em coisas do demônio (Heine, 1991, p. 32-33).

Lutero, segundo Heine, é um típico frade nórdico. Por isso, ele jamais poderia compreender alguém como o Papa Leão X. Aliás, parece não haver nenhuma possibilidade de que um pudesse entender o outro. Lutero é, tal como também defenderá Nietzsche, um típico frade alemão que não consegue enxergar a superação do cristianismo na sua própria sede ${ }^{10}$. Leão $X$ é um típico representante do cristianismo da decadência que também não é capaz de enxergar quais eram os valores reivindicados por Lutero. Por isso, de forma absolutamente perspicaz e humorística, Heine toma a defesa do Papa Leão X:

\footnotetext{
${ }^{9}$ BENJAMIN, W. Origem do drama trágico alemão. Belo Horizonte: Autêntica, 2013.

${ }^{10}$ Refiro-me especialmente a parte final do aforismo 61 (pp.78-79).

\begin{tabular}{|c|c|c|c|c|}
\hline Rovista Dialectus & Ano 5 & n. 12 & Janeiro - Julho 2018 & p. $241-264$ \\
\hline
\end{tabular}
}


Com efeito, se me sondassem interiormente, confessaria que no fundo o Papa Leão $\mathrm{X}$ era muito mais razoável que Lutero e que este de forma alguma compreendeu os fundamentos últimos da Igreja Católica. Pois Lutero não compreendeu que a ideia do cristianismo, a destruição da sensualidade, estava demasiadamente em desacordo com a natureza humana para ser, um dia, plenamente realizada na vida; não compreendeu que o catolicismo era como uma concordata entre Deus e o Diabo, isto é, entre o espírito e a matéria... um sábio sistema de concessões que a Igreja fez em favor da sensualidade... Podes dar ouvidos às ternas inclinações do coração e tomar uma bela moça em teus braços, mas depois terás que confessar que isso foi um pecado vergonhoso e pagar penitências por eles. Que essas penitências pudessem ser feitas através do dinheiro, isso era tão benéfico para a humanidade como útil para a Igreja. A Igreja, por assim dizer, deixava que se pagasse indulto por cada gozo carnal... O comércio de indultos não era um abuso, era uma consequência de todo o sistema eclesiástico e, ao atacá-lo, Lutero atacou a própria Igreja, que teve que condená-lo como herege. (Heine, 1991, p. 34-35).

Desse modo, o protestantismo germânico é, no entender do pensador, algo frio e gelado, totalmente incapaz de compreender a vida, o desejo e a natureza. Por isso, segundo Heine, o protestantismo facilita o exercício das virtudes cristãs:

Nós, nórdicos, somos de sangue frio e não precisávamos de tantas cartas de indulgência quantas o paternalmente solícito Leão nos enviava. $\mathrm{O}$ clima nos facilitava o exercício das virtudes cristãs e, em 31 de Outubro de 1517, quando Lutero afixou suas teses contra as indulgências nas portas da Igreja de Agostinho, o fosso da cidade de Wittenberg talvez já estivesse gelado e nele talvez já se pudesse andar sobre patins que, sendo um prazer bastante frio, não é portanto, um pecado (Heine, 1991, p. 35).

Por detrás de toda a comicidade de Heine, podemos enxergar aqui qual é o debate filosófico em questão, isto é, trata-se de uma polêmica entre o cristianismo protestante e o sensualismo do cristianismo católico. Dessa forma, o real motivo da Reforma é a luta do espírito contra o sensualismo:

A luta contra o catolicismo na Alemanha não foi senão uma guerra desencadeada pelo espiritualismo, quando percebeu que apenas usava o título de soberano e imperava apenas de jure, enquanto o sensualismo, por fraude habitual, exercia a verdadeira soberania e imperava de fato - os comerciantes de indulgências foram perseguidos, as belas concubinas dos sacerdotes trocadas por frias esposas, destruíram-se atraentes imagens de Madonas, surgindo aqui e ali o puritanismo mais hostil à sensualidade (Heine, 1991, p. 36). 
Tal conceituação de cristianismo protestante e católico é de fundamental importância para entender a diferença entre a recusa dos franceses a tudo que fosse eclesiástico e a luta dos protestantes alemães contra o catolicismo. É verdade que ambos lutam contra o catolicismo. Contudo, os alemães, no entender de Heine, lutam de forma grave e pesada, visto que o seu protestantismo possui tal natureza. Os franceses lutam com leveza, visto que não estão influenciados por nenhuma concepção protestante, mas pela sátira e por alguns dos ideais mais caros do iluminismo:

Assim, enquanto na Alemanha se lutava com recatada gravidade, aqui se luta com gracejo lascivo; e, enquanto ali se travava uma disputa teológica, aqui se compunha uma sátira jocosa qualquer. Geralmente o objeto dessa sátira era mostrar a contradição que o homem cai consigo mesmo quando quer ser completamente espírito; e assim floresceram as mais deliciosas histórias de homens pios que, involuntariamente, sucumbem a sua natureza animal ou querem manter a aparência de devoção e se refugiam na hipocrisia (Heine, 1991, p. 36).

As objeções ao espiritualismo não são gratuitas. Embora Heine reconheça o seu valor, ele não pode aceitar, em hipótese alguma, que o mesmo se afirme em detrimento do sensual. Para ele, o espiritualismo só existe visto que o sensual da matéria pode ser efetivamente afirmado:

\begin{abstract}
Mas por que o espiritualismo nos é tão repulsivo? É algo tão ruim? Absolutamente. Essência de rosas é algo precioso, e um pequeno frasco dela é refrescante quando se tem de consumir seus dias nos aposentos reservados de um harém. Não queremos, no entanto, que se pisem e espezinhem todas as rosas desta vida para que se obtenham algumas gotas de essência, por mais reconfortante que seja seu efeito (Heine, 1991, p. 37-38).
\end{abstract}

Contudo, mesmo o protestantismo que, nos seus primórdios, era fiel representante do espiritualismo, se altera e, aos poucos, vai se tornando sensual. Entretanto, com o passar dos anos, o espiritualismo retoma o controle da situação, mas é ferido por um inimigo engendrado dentro de si mesmo, isto é, pela filosofia:

Por toda parte se abriam as portas dos conventos, e freiras e mongezinhos se abraçavam e beijocavam uns aos outros. A história aparente dessa época, com efeito, consiste quase exclusivamente em revoltas sensualistas. Mais tarde veremos o quão pouco restou disso, como o espiritualismo reprimiu novamente esses desordeiros, como paulatinamente assegurou a soberania no norte, mas foi mortalmente ferido por um inimigo que nutriu em seu próprio seio, a saber, a filosofia (Heine, 1991, p. 38).

\begin{tabular}{|c|c|c|}
\hline Q Rovista Dialectus & Ano 5 & n. 12 \\
\hline
\end{tabular}


A interpretação de Lutero feita por Heine pode ser lida quase que em uníssono com a interpretação nietzschiana do reformador. Para ambos, Lutero é mais do que um simples homem, mas um símbolo de uma época, um monge que nega a vida e seus instintos:

Esse homem era Martinho Lutero, o pobre monge escolhido pela Providência para romper o poderio mundial romano, contra o qual os imperadores mais poderosos e os sábios mais astutos já haviam inutilmente lutado. A Providência, no entanto, sabe muito bem em que ombros põe os seus fardos; aqui não era necessário apenas força espiritual, mas também força física. Para suportar os esforços dessa tarefa, era preciso de um corpo fortalecido desde a juventude pela austeridade e castidade monásticas (Heine, 1991, p. 39).

Lutero se torna o símbolo alemão por excelência. Seu caráter, suas virtudes e seus defeitos passam a ser a marca de todos os alemães. Seu modo severo é ao mesmo tempo cordial, sua crença contrasta com suas dúvidas, seu jeito místico faz oposição ao seu modo empreendedor. O reformador traz em si todas as contradições que formam o protótipo do novo homem alemão: “O mesmo homem que podia xingar como uma vendedora de peixes, também podia ser afável como uma virgem terna" (Heine, 1991, p. 40). Entretanto, o que Heine destaca é que Lutero vai além da discussão entre espiritualismo e sensualismo. O reformador apresenta dois pontos centrais para uma nova discussão da religião: a Bíblia como fonte única de autoridade e os argumentos racionais. Com tais elementos, Lutero acaba com qualquer perspectiva indo-gnóstica no cristianismo e inicia o chamado cristianismo evangélico, baseado nas crenças judaicodeístas. A partir de tais teses que, primeiramente pareciam versar apenas sobre religião, pode-se agora discutir uma infinidade de outras coisas, inclusive, a própria legitimidade da fé:

O sacerdote se torna um ser humano, desposa uma mulher e gera filhos, tal como Deus o exige. Em compensação, Deus volta a ser um celestial solteirão sem família; contesta-se a legitimidade de seu filho; demitem-se os santos; cortam-se as asas dos anjos; a mãe de Deus perde todos os direitos à coroa e proíbem-na de fazer milagres. Os milagres cessam a partir daí, mas especialmente depois que as ciências naturais fazem tão grandes progressos (Heine, 1991, p. 41). 
A razão adquire em Lutero, segundo Heine, o papel de uma juíza. Dela procede "o direito de explicar a Bíblia, e ela, a razão, foi reconhecida como juíza suprema em todos os litígios religiosos" (Heine, 1991, p. 43). Novamente Lutero é aqui inovador, rompendo com a antiga tradição escolástica, que separava as verdades em duas modalidades: verdades teológicas e verdades filosóficas. Por isso, Heine louva Lutero pela liberdade de pensamento propiciada e compreende que a Reforma foi de vital importância para todo esse processo.

Contudo, com a costumeira comicidade, Heine aponta que, com a entrada de alguns príncipes no processo reformador (especialmente Frederico II da Prússia), as teses outrora inovadoras passam a adquirir um caráter profundamente autoritário: "Naturalmente, as coisas mudaram desde então, e o patrono natural de nossa liberdade de pensamento protestante se entendeu com o partido Ultramontano no sentido de suprimi-la, para isso utilizando a arma que o papado concebeu e usou por primeiro contra nós: a censura (Heine, 1991, pp. 43-44).

Tal censura acaba por atingir academias e universidades e os príncipes, que outrora pareciam tão adeptos da liberdade e do livre pensamento protestante, resolvem mudar de opinião:

E que valeria toda a ciência, estudo ou cultura para os príncipes, se a sagrada segurança dos seus tronos estivesse ameaçada! Eles seriam suficientemente heróicos para sacrificar todos esses bens relativos em prol do único bem absoluto: a soberania absoluta. Pois esta lhes foi confiada por Deus, e, quando o Céu manda, todas as ponderações terrenas têm de ceder (Heine, 1991, p. 45).

Lutero é mais do que apenas um reformador religioso, ainda que isso tenha alterado não somente o ambiente religioso, mas todo um contexto histórico, político e filosófico. Para Heine, ele é o criador da língua alemã e assim se firmou com a sua tradução da Bíblia para o seu idioma natal. Além disso, o reformador é ainda um amante da música, um teólogo que fazia música ao escrever. Por isso, não fortuitamente, uma das marcas características do protestantismo é o apreço pela música, pelas melodias elaboradas e pelas letras claras e expressivas.

A literatura alemã antes de Lutero se caracteriza por ter uma marcada luta entre o cristianismo e a religião nórdica e por espelhar essa convivência, notadamente nos épicos medievais. Depois de Lutero surge a chamada verdadeira

\begin{tabular}{|c|c|c|}
\hline Q Rovista Dialectus & Ano 5 & n. 12 \\
\hline
\end{tabular}


religião, isto é, ela estimula a prática, por isso advém daí uma nova filosofia, a indústria e o novo comércio. Surge o conceito de clássico e as divisões históricas parecem ficar mais evidentes. Entretanto, o ponto central no entender de Heine está na questão do indivíduo. O luteranismo coloca o sujeito diante de Deus e, por isso, ajuda no nascimento daquilo que conhecemos como filosofia moderna e como ceticismo.

\section{O segundo livro de Contribuição à história da religião e da filosofia na Alemanha}

O objetivo do livro segundo é dissertar mais efetivamente sobre a filosofia alemã. Todavia, nunca se pode esquecer que tal tipo de explicação, notadamente na filosofia alemã, nunca consegue ser feito em separado da religião. Heine aborda aqui oito pensadores: Descartes, Leibniz, Wolff, Espinosa, Jacobi, Paracelso, Jacob Bohme e Lessing. Além deles, surgem referências a Kant, Schelling, Hegel e Fichte, que serão analisados no terceiro livro. Trata-se, evidentemente, de uma espécie de panorama da história da filosofia alemã e, como todo panorama, não consegue apresentar a totalidade. Todavia, com extrema ironia e perspicácia, Heine consegue tocar e esboçar um primeiro esforço em compreender diversos temas importantes do pensamento germânico.

O primeiro filósofo abordado será Descartes. No entender de Heine, ele será o primeiro filósofo moderno. Entretanto, a rigor, ele não era alemão. Contudo, para o pensador, ele seria o mais alemão dentre todos os filósofos franceses:

\footnotetext{
O pai da filosofia moderna não é Bacon, como se costuma ensinar, mas Descartes, e mostraremos, de modo bem claro, em que medida a filosofia alemã dele descende.

René Descartes é um francês e, também aqui, cabe à grande França a glória da iniciativa. Mas a grande França, a terra dos barulhentos, buliçosos e loquazes franceses, jamais foi solo adequado para a filosofia, na qual talvez essa jamais floresça e sentindo isso, Descartes foi para a Holanda... (Heine, 1991, p. 53).
}

Segundo Heine, a filosofia de Descartes espelha o seguinte conflito: a eterna batalha entre espiritualismo/idealismo/racionalismo e sensualismo/materialismo/empirismo. Sem entrar no mérito e no significado de cada

\begin{tabular}{|l|l|l|l|l|}
\hline Q Povista Dialectus & Ano 5 & n. 12 & Janeiro - Julho 2018 & p. 241-264 \\
\hline
\end{tabular}


uma dessas palavras, a questão crucial aqui é reenviada para uma polêmica mais antiga da história da filosofia, a saber, a disputa entre o legado platônico e o legado aristotélico: "Ainda que com outros nomes, trata-se sempre de Platão e Aristóteles" (Heine, 1991, p. 59). A França, no entender de Heine, seria herdeira do empirismo que, por sua vez, remontaria às teses aristotélicas. Já a Alemanha representaria a herança idealista, ou seja, platônica.

O segundo filósofo mencionado por Heine é Leibniz. Para ele, Leibniz é herdeiro da tradição idealista de Descartes e com suas doutrinas matemáticas e, notadamente com a explicação sobre as mônadas, causa impacto no ambiente filosófico alemão. Todavia, segundo nosso autor, sua outra obra Teodiceia ${ }^{11}$, a despeito de ter sido bastante discutida na Alemanha, foi seu trabalho menos satisfatório: "Entre todos os escritos de Leibniz, Teodiceia foi o mais discutido na Alemanha. E, no entanto, sua obra filosófica mais fraca" (Heine, 1991, p. 58). A suposta fraqueza da obra de Leibniz se deve ao fato de que a mesma tenta articular uma resposta racional para diversas questões centrais do cristianismo num tempo onde isso não parece ser bem recebido. Por isso, não fortuitamente, o destino dela foi receber a mais severa crítica dos seus contemporâneos.

Se Leibniz se caracteriza por ser um discípulo de Descartes, Wolff, o terceiro filósofo aqui mencionado, é caracterizado como um leibniziano pietista que, no entender de Heine, foi um homem de grandes méritos. Para ele, Wolff, a despeito de criar uma certa prisão para as ideias de Leibniz, é o responsável pelo exercício da filosofia em alemão:

Chama-se Christian Wolff o homem primoroso que não apenas sistematizou, mas também apresentou as ideias de Leibniz em alemão. Seu verdadeiro mérito não consiste em ter encerrado as ideias de Leibniz em um sólido sistema e, menos ainda, em tê-las tornado acessíveis ao grande público através da língua alemã; seu mérito consiste em ter-nos estimulado a também filosofar em nossa língua materna. Se até Lutero só soubéramos tratar de teologia em latim, da mesma forma foi só em latim que, até Wolff, soubemos tratar de filosofia (Heine, 1991, p. 69).

Entretanto, o mesmo Wolff teve relações com o movimento religioso pietista, que se caracterizava por uma busca da piedade cristã em meio a uma religião

${ }^{11}$ LEIBNIZ, G.W. Ensaios de teodiceia: sobre a bondade de Deus, a liberdade do homem e a origem do mal. São Paulo: Estação Liberdade, 2013.

\begin{tabular}{|l|l|l|l|l|}
\hline Q Rovista Q Dialectus & Ano 5 & n. 12 & Janeiro - Julho 2018 & p. 241-264 \\
\hline
\end{tabular}


que se acreditava excessivamente racionalizada. Para Heine, ao assumir tal postura, o pensador antecipa-se a Hegel, que realizará a efetiva junção entre razão e religião. Segundo nosso autor, trata-se de uma relação imprópria, isto é, Wolff se serve da religião e essa se serve do seu suporte intelectual, não se dando conta de que esse também é seu caminho de destruição: "A partir do instante em que uma religião busca auxilio na filosofia, seu declínio é inevitável. Ela procura se defender e se enreda cada vez mais na destruição" (Heine, 1991, p. 75).

Outro filósofo não alemão mencionado será o holandês, filho de portugueses fugitivos da Inquisição, Bento de Espinosa (ou Baruch, tendo em vista que se tratava de uma família judaica). Heine discorrerá longamente sobre a biografia pessoal de Espinosa e notadamente sobre os seus sofrimentos e sobre a sua faceta de um mártir do pensamento moderno. Ele assinala que o pensador defende a existência de uma substância única, eterna e imutável. Ressaltando, a partir desse ponto, sua importância para o pensamento moderno:

\footnotetext{
A moderna filosofia da natureza possui apenas o mérito de ter provado, da maneira mais sagaz, o eterno paralelismo existente entre espírito e matéria. Digo espírito e matéria, empregando tais expressões como sinônimos daquilo que Espinosa chama de pensamento e extensão. De certo modo, também são sinônimos daquilo que nossos filósofos da natureza chamam de espírito e natureza, ou o ideal e o real (Heine, 1991, p. 64).
}

A presença de Espinosa no texto de Heine aparece também em alguns outros momentos. Sua importância é enfatizada na ética e há uma referência ao seu Tratado teológico - político ${ }^{12}$. Contudo, o pensador também aparece nas digressões feitas por Heine. No seu texto, há uma longa exposição do panteísmo e sua defesa em relação ao deísmo:

... a Alemanha é o solo mais fértil para o panteísmo; é a religião de nossos maiores pensadores, de nossos melhores artistas, e lá o deísmo já há muito tempo ruiu na teoria, conforme relatarei mais tarde. Como muitas outras coisas, ainda se conserva, sem nenhuma justificação racional, apenas na massa irrefletida. Ninguém diz, mas todo mundo sabe; o panteísmo é o segredo público na Alemanha. Na verdade, já estamos muito crescidos para o deísmo. Somos livres e não queremos um tirano tonitruante. Somos emancipados e não precisamos de cuidados paternais. Também não somos

${ }^{12}$ ESPINOSA, B. Tratado teológico-político. São Paulo: Martins Fontes, 2008.

\begin{tabular}{|l|l|l|l|l|}
\hline Q Rovista Dialectus & Ano 5 & n. 12 & Janeiro - Julho 2018 & p. 241-264 \\
\hline
\end{tabular}


obras mal feitas de um grande mecânico. O deísmo é a religião para servos, para crianças, para genebrinos, para relojoeiros (Heine, 1991, p. 68).

O quinto dos filósofos citados por Heine será Jacobi. Tal pensador caracteriza-se por sua crítica violenta a Espinosa e por abdicar do uso da razão, colocando-a sempre numa posição secundária. Por isso, nosso autor afirma que o mesmo nada é se comparado com a grandiosidade de Espinosa e que, além disso, ele não passa de uma grande toupeira: "Que toupeira! Não viu que a razão se assemelha ao sol eterno, que ilumina sua trajetória com luz própria, enquanto passeia seguro lá no alto. Não há nada que se compare ao ódio piedoso, benevolente, do pequeno Jacobi contra o grande Espinosa" (Heine, 1991, p. 69).

Dois outros autores enumerados aqui apenas de forma crítica e sem nenhuma relevância para a filosofia alemã são Paracelso e Jacob Bohme. O primeiro se caracteriza por seu charlatanismo e por seus experimentos suspeitos em alquimia. $\mathrm{O}$ segundo teria relações com o movimento teosófico, estando mais próximo do misticismo.

Antes de citar o oitavo pensador, que será Lessing, Heine faz uma nova digressão, desta vez, sobre a polêmica entre pietistas e ortodoxos no pensamento religioso alemão. A ortodoxia protestante se estabeleceu logo após a formação efetiva da nova Igreja e, aos poucos, foi implantando sua legislação, seu cânone e seus dogmas. O protestantismo, vagarosamente, começa a se tornar uma religião legalista e sem nenhuma afetividade ou relação com as coisas da vida cristã. Em reação a tal movimento, surge um grupo denominado de pietistas. O intuito de tal grupo é reintroduzir no cristianismo protestante a afetividade e a religião do coração e da emoção. Seu principal expoente foi Spener, célebre autor da obra Pia Desideria ${ }^{13}$. O movimento de piedade teve uma importância crucial na história do protestantismo, estimulando-o às obras sociais e missionárias, gerando reflexos, inclusive, no resto da Europa e na América do Norte.

O intuito de Heine é explicar, notadamente para o público francês, diversas das disputas teológicas alemãs e todo o ódio envolvido no processo. Segundo ele, os franceses, formados na tradição católica, não conseguem ter a real dimensão do que isso efetivamente significa. Aliás, nosso pensador aponta que o ódio é um dos

${ }^{13}$ SPENER, P.J. Pia Desideria. São Bernardo do Campo: Imprensa Metodista, 1985.

\begin{tabular}{|l|l|l|l|l|}
\hline Q Rovista Dialectus & Ano 5 & n. 12 & Janeiro - Julho 2018 & p. 241-264 \\
\hline
\end{tabular}


constituintes do modo de ser alemão. Para ele, até o ódio alemão é idealista, isto é, possui raízes profundas:

\begin{abstract}
Isso vem do fato de serem idealistas também no ódio. Não nos odiamos por causa de coisas externas como vocês, por exemplo, por causa da vaidade ferida, de um epigrama, de um cartão de visita não respondido; em nossos inimigos odiamos neles o que há de mais profundo, o que há de mais essencial: o pensamento. Vocês, franceses, são levianos e superficiais, tanto no amor quanto no ódio. Nós, alemães, odiamos de maneira profunda, persistente; sendo muito honrados, muito desajeitados para nos vingar de uma rápida perfídia, odiamos até o nosso último suspiro.
\end{abstract}

'Conheço, senhor, essa calma alemã', disse recentemente uma senhora fitando-me, incrédula e temerosa, com os olhos esbugalhados. 'Sei que vocês, alemães, empregam a mesma palavra para perdoar e envenenar. E, de fato, ela tem razão: Vergeben significa as duas coisas (Heine, 1991, p. 74).

O terrível destino do cristianismo na Alemanha depois da Reforma é ter se transformado em moral, abstraindo-se de qualquer tipo de perspectiva histórica. Ao romper com a tradição do catolicismo, o cristianismo protestante deixa de enfatizar sua relação com a história e se perde. Logo, a moral se constitui num dos seus pontos de apoio. Por isso é que, não sem intencionalidade, perceberemos em filósofos como Kant, por exemplo, toda uma carga moral de origem protestante, com um forte apelo ao indivíduo e sua consciência.

Heine também deseja destruir um outro mito germânico admirado na França: o rei Frederico II da Prússia. O célebre monarca é bastante louvado pelos franceses chegando, inclusive, a ser denominado de Salomão nórdico por Voltaire. Sua característica de ser um rei iluminista e de mentalidade universal, seduz boa parte da intelectualidade da época. Entretanto, nosso autor aponta que Frederico menosprezou a cultura alemã e sua língua. Além disso, ocorreram censuras em seu governo iluminista. Heine, diferentemente de Kant, que vive a louvar o monarca, é severo critico do seu governo, tal como também fará Nietzsche.

Por fim, ele analisa o oitavo pensador: Lessing, que será sobejamente elogiado. Sua formação privilegiada é bastante admirada e louvada. Lessing, desde os primeiros anos, estudou línguas clássicas e humanidades em geral, destacando-se, ainda muito jovem, como um brilhante pensador. A influência de Espinosa em sua obra é marcante. Entretanto, sua interpretação de Leibniz será ainda mais forte. Para Lessing, tal como para Leibniz, existiam duas modalidades de razão: verdades de fato e verdades

\begin{tabular}{|l|l|l|l|l|}
\hline Q Povista Dialectus & Ano 5 & n. 12 & Janeiro - Julho 2018 & p. 241-264 \\
\hline
\end{tabular}


de razão. O cristianismo estaria ligado ao primeiro tipo, enquanto a matemática estaria ligada ao segundo tipo. Com tal distinção, Lessing cria um espaço racional para a fé cristã, mas, ao mesmo tempo, aponta que há um grande fosso que separa fé e razão, tal como fará, anos mais tarde, também por sua influência direta, o dinamarquês Kierkegaard em Temor e tremor ${ }^{14}$. Por isso, o cristianismo seria uma proposta paradoxal que se chocaria com a razão e, nesse sentido, sua tese rememora também o pensamento de Pascal, mas antecipa o pensamento do autor de Copenhague, que considera o cristianismo como um escândalo (visto que supera qualquer lei) e como uma loucura (visto que ultrapassa a racionalidade à moda grega).

Lessing contribui ainda com a defesa do diálogo permanente entre as religiões, com o entendimento claro da relação entre o cristianismo e a filosofia grega e com suas investigações acerca da estética e da arte. Por todos esses motivos, Heine não poupa elogios a ele, comparando-o a Lutero:

\begin{abstract}
Digo que Lessing deu continuidade a Lutero. Depois que Lutero nos libertou da tradição e elevou a Bíblia à única fonte do cristianismo, surgiu, como já relatei acima, um rígido culto da palavra, e a letra da Bíblia imperou tão tiranicamente quanto outrora a tradição. Lessing foi o que mais contribui para que se libertasse dessa letra tirânica. Assim como Lutero não foi o único a combater a tradição, Lessing também não lutou sozinho, mas foi o mais violento contra a letra (Heine, 1991, p. 85).
\end{abstract}

\title{
3. O terceiro livro de Contribuição à história da religião e da filosofia na Alemanha
}

Heine começa o livro terceiro com uma citação curiosa: uma referência indireta à obra Frankenstein ou o moderno Prometeu de Mary Shelley ${ }^{15}$. Sua metáfora é cheia de significado. Trata-se de uma crítica à concepção deísta e mecanicista inglesa, que se julgava capaz de criar a própria vida.

Quatro pensadores serão abordados neste livro: Kant, Fichte, Schelling e Hegel. Sobre Kant, Heine fornece fartos dados bibliográficos e anedóticos, relembrando os seus célebres hábitos severos, sua pontualidade e sua postura celibatária. Entretanto, para além de tais considerações, há uma importante percepção da importância da Crítica

\footnotetext{
${ }^{14}$ KIERKGAARD, S.A. Temor e tremor. Lisboa: Relógio D’Água, 2009.

${ }^{15}$ SHELLEY, M. Frankenstein ou o moderno Prometeu. Porto Alegre: LPM, 1997.

\begin{tabular}{|l|l|l|l|l|}
\hline Q Povista Qialectus & Ano 5 & n. 12 & Janeiro - Julho 2018 & p. 241-264 \\
\hline
\end{tabular}
}


da razão pura ${ }^{16}$ no cenário filosófico germânico: "Dizem que os espíritos noturnos ficam aterrorizados se se lhes apresentasse a Crítica da Razão Pura de Kant! Esse livro é a espada com que se executou o deísmo na Alemanha” (Heine, 1991, p. 89)

A primeira coisa a se notar é que a crítica kantiana consegue, no entender de Heine, ser tão potente do ponto de vista filosófico quanto foram as armas durante a Revolução Francesa. Em outras palavras, ela fornece o suporte intelectual para uma mudança de atitude. Além disso, sua Crítica da razão pura ao demonstrar, por meio de fórmulas matemáticas, qual é a real extensão do nosso conhecimento, terminou por solapar os últimos fundamentos da metafísica. Tal coisa ocorre quando Kant divide as coisas em duas esferas: o mundo dos fenômenos (que podemos conhecer) e a coisa em si (que não somos capazes de conhecer). Ao operar tal distinção, Kant destrói qualquer tentativa teológica de provar a existência de Deus e qualquer concepção deísta.

Kant também opera, com sua filosofia, algo que ele mesmo denominou como a revolução copernicana na história do pensamento. Até ele, os filósofos se dividiam em dois grupos: inatistas e empiristas. Os primeiros se caracterizam como um grupo que ia de Platão a Descartes, tendo como sua marca a defesa das idéias inatas como forma de conhecimento. O segundo grupo se caracteriza por defender que as idéia se formavam na mente na medida em que percebemos as coisas. Tal grupo possuía uma variação que ia desde alguns antigos pré-socráticos até autores como Hobbes, Locke, Hume. Kant aponta o acerto e o erro das duas posições. Para ele, nós temos a forma do conhecimento, mas os conteúdos são dados pela experiência. Desse modo, o pensador concilia os dois polos e cria uma divisão na história da filosofia ocidental.

Contudo, a despeito de todos os seus méritos, Heine julga que a filosofia de Kant conduziria naturalmente a um processo de descrença, mas ele, ao contrário de alguns outros filósofos, não teria tido a coragem de seguir adiante nas suas investigações e negar, por meio de sua filosofia, a crença em Deus:

Será que, ao destruir todas as provas da existência de Deus, quis nos mostrar justamente como é desagradável se nada podemos saber da existência de Deus? Nisso agiu quase tão sabiamente quanto meu amigo westfaliano que quebrou todos os lampiões da Rua Grohnder, em Göttingen e, estando nós no escuro, proferiu um longo discurso sobre a necessidade prática dos lampiões, que quebrara apenas teoricamente para nos mostrar que nada poderíamos ver sem eles (Heine, 1991, p. 98).

${ }^{16}$ Kant, I. Crítica da razão pura. São Paulo: Martins Fontes, 1993.

\begin{tabular}{|l|l|l|l|l|}
\hline Qevista Dialectus & Ano 5 & n. 12 & Janeiro - Julho 2018 & p. 241-264 \\
\hline
\end{tabular}


Ao analisar a filosofia de Fichte, Heine novamente fornece fartos dados biográficos da vida do filósofo e explora, de forma especial, sua relação de amizade com Kant. São retratados inúmeros episódios jocosos de sua vida, inclusive, sua célebre viagem até a cidade onde Kant residia e sua falta de dinheiro para retornar, visto que Kant também não pôde ajudá-lo financeiramente. Entretanto, além desses dados biográficos e das histórias engraçadas, nosso autor enfatizará a importância de Fichte como alguém que radicalizou a subjetividade proposta por Kant, transformando a ideia do eu em ponto central de sua filosofia. Sua principal obra foi Doutrina da ciência ${ }^{17}$. No entender de Fichte, "todas as coisas têm realidade apenas em nosso espírito".

Além da relação com Kant, outra amizade será fundamental na trajetória intelectual de Fichte: Goethe. Para Heine, o escritor alemão teria realizado, de modo literário, o que Fichte realizará em sua filosofia. Entretanto, Heine também crítica a idéia fichtiana sobre Deus:

De fato, não se sabe ao certo se é por ironia ou mero delírio que Fichte depura o amado Deus de todo ingrediente sensível e, apenas enquanto tal, possível! A doutrina-da-ciência, diz, não conhece outro ser senão o ser sensível e, uma vez que só se pode atribuir um ser a objetos da experiência, esse predicado não pode ser aplicado a Deus. Por isso, o Deus fichtiano não possui existência alguma, não é, manifesta-se apenas como puro agir, como uma ordem de eventos, como ordo ordinans, como lei do universo (Heine, 1991, p. 112).

Seguindo na mesma trilha de Fichte (e dos pós-kantianos), encontramos Schelling que, no entender do próprio Fichte simplesmente continuou a sua filosofia, acrescentando-lhe apenas a ideia de natureza. Em outras palavras, Schelling parte do eu para os fenômenos, mas também acrescenta a natureza a esse eu que parte dos fenômenos. Schelling é o introdutor da ideia de absoluto. Sua tentativa é intuir o mundo dos fenômenos a partir do eu e da natureza. Contudo, não consegue obter bom êxito nesse empreendimento. Com efeito, ele não consegue ir além daquilo que Espinosa já realizara. Suas propostas terminam no reino da poesia e confundem totalmente ideal e real, não conseguindo alcançar nenhum tipo de reconciliação. Por isso, Heine ressalta que seu grande mérito foi prenunciar a chegada de Hegel:

${ }^{17}$ FICHTE, J.G. Fundamentos da doutrina da ciência completa. Lisboa: Colibri, 1996.

\begin{tabular}{|l|l|l|l|l|}
\hline Qovista Dialectus & Ano 5 & n. 12 & Janeiro - Julho 2018 & p. 241-264 \\
\hline
\end{tabular}


Creio que a trajetória intelectual do senhor Schelling se encerra com a tentativa de intuir intelectualmente o Absoluto. Agora, entra em cena um pensador maior, que desenvolve a filosofia da natureza num sistema acabado, elucida todo o mundo dos fenômenos a partir de sua síntese, completa as grandes ideias de seus predecessores com ideias ainda maiores, realizando-as por todas as disciplinas e fundamentando-as, pois, cientificamente. É um discípulo do senhor Schelling, mas um discípulo que, no reino da filosofia, aos poucos se apropriou do poder do mestre, deixou arrogantemente de obedecer-lhe e, finalmente o lançou na obscuridade. Eis o grande Hegel, o maior filósofo que a Alemanha já produziu desde Leibniz (Heine, 1991, p. 122-123).

No entender de Heine, com Hegel, "nossa revolução filosófica está encerrada. Hegel fechou o grande ciclo" (Heine, 1991, p. 123). Seu gigantesco trabalho, tal como o de Kant, será responsável por uma divisão de águas na história do pensamento. Se Kant, promoveu a revolução copernicana na teoria do conhecimento e trouxe toda uma série de pensadores denominados pós-kantianos, caracterizados pela ênfase na subjetividade e ora esbarrando na poesia e no sentimentalismo, Hegel também trará, na esteira de sua filosofia, tanto os pensadores que aperfeiçoam o seu sistema quanto aqueles que o recusam. Por isso, surgiu na filosofia o título de pós-hegeliano. Tal nomenclatura serve para designar uma gama de autores: ateus, marxistas, existencialistas e niilistas.

Hegel e sua dialética buscam a reconciliação do indivíduo e da natureza, do indivíduo e do Estado, do indivíduo e do coletivo religioso. Tais questões são capitais em qualquer filosofia depois do século XIX e por isso espelham, com seus acertos e seus erros, todo um panorama da história da religião e da filosofia na Alemanha.

\section{Conclusão}

Segundo podemos avaliar, o grande mérito da obra de Heine sobre a relação entre religião e filosofia na Alemanha foi, na verdade, estabelecer uma singular distinção entre dois tipos de iluminismo, a saber, o iluminismo francês (lumières) e o iluminismo alemão (Aufklärung). O primeiro tipo de iluminismo ainda que possa fazer forte oposição à aspectos religiosos, não brota do cerne da própria religião, mas antes se constrói em torno de um anti-clericalismo particular e, nesse caso, a herança católica francesa faz toda a diferença. Já o iluminismo alemão nasce, antes de mais nada, do

\begin{tabular}{|c|c|c|c|c|}
\hline Revista Dialectus & Ano 5 & n. 12 & Janeiro - Julho 2018 & p. $241-264$ \\
\hline
\end{tabular}


cerne da própria religião, de uma espécie de compromisso cristão que, posteriormente, desdobra-se num combate entre crentes, descrentes, apostatas, ateus e agnósticos. Nesse caso, o protestantismo alemão parece também fazer toda a diferença. Note-se, contudo, que todas essas categorias brotam do próprio solo religioso e, nesse sentido, talvez a própria secularização apareça de modo distinto tanto na Alemanha como na França, tal como também já aponta Marramao em Céu e Terra-genealogia da secularização ${ }^{18}$.

Seguindo tal senda, Löwith é mais um dos pensadores que irá explorar o conceito de secularização como algo que brota do solo alemão protestante e, nesse sentido, mesmo o ateísmo pós-hegeliano do século XIX seria, aos seus olhos, um filho da Reforma Protestante. Tal tese é defendida com vigor tanto no seu De Hegel a Nietzsche, onde há menções explicitadas a Heine ${ }^{19}$ e também no seu $O$ Sentido da história, onde o Manifesto Comunista de Marx e Engels, por exemplo, nada mais seria do que uma espécie de novo evangelho secularizado, usando as mesmas categorias do messianismo judaico e agora aplicando-as ao contexto político ${ }^{20}$.

Um outro tipo de exercício, bastante singular e meritório, nos é apresentado pelo espanhol Arsenio Guinzo Fernández. Com extrema argúcia - e certamente inspirado nas reflexões de Heine e de Hegel - o autor desenvolve no seu Protestantismo e filosofia, um inventário que vai dos dias de Lutero a Schopenhauer, mostrando como a recepção luterana modulou, na verdade, toda a moderna filosofia alemã. Por isso, Nietzsche parece ter alguma razão quando, no aforismo 10 do Anticristo, afirma que "o pastor protestante é o avô da filosofia alemã e o protestantismo é o seu peccatum originale" (Nietzsche, 2007, p.16). Desse modo, o que parece sempre haver fascinado os estudiosos da filosofia alemã é um encantamento pela história dos seus próprios pecados ancestrais, que se multiplicaram em inúmeras filosofias.

\section{REFERÊNCIAS}

BENJAMIN, W. Origem do drama trágico alemão. Belo Horizonte: Autêntica, 2013.

ESPINOSA, B. Tratado teológico-político. Martins Fontes: São Paulo, 2008.

\footnotetext{
${ }^{18}$ MARRAMAO, G. Céu e Terra - genealogia da secularização. São Paulo: UNESP, 1997.

${ }^{19}$ Notadamente nas pp. 52-53.

${ }^{20}$ Notadamente o capítulo II da seguinte obra: LÖWITH, K. O sentido da história. Lisboa: Edições 70, 1991.
}

\begin{tabular}{|l|l|l|l|l|}
\hline Qenista Dialectus & Ano 5 & n. 12 & Janeiro - Julho 2018 & p. 241-264 \\
\hline
\end{tabular}


FERNÁNDEZ, Arsenio Ginzo. Protestantismo y filosofia - la recepción de la Reforma em la filosofia alemana. Alcalá: Universidad de Alcalá, 2000.

FEUERBACH, L. A Essência do cristianismo. Petrópolis: Vozes, 2009.

FICHTE, J.G. Fundamentos da doutrina da ciência completa. Lisboa: Colibri, 1996.

FREUD, S. O futuro de uma ilusão. Porto Alegre: LPM, 2010.

HEGEL, G.W.F. Lecciones sobre la filosofía de la historia universal. Madrid: Alianza Editorial, 1984.

HEINE, H. Contribuição à história da religião e da filosofia na Alemanha. São Paulo: Iluminuras, 1991.

KANT, I. Crítica da razão pura. São Paulo: Martins Fontes, 1993.

KIERKGAARD, S.A. Temor e tremor. Lisboa: Relógio D’Água, 2009.

LEIBNIZ, G.W. Ensaios de teodiceia: sobre a bondade de Deus, a liberdade do homem e a origem do mal. São Paulo: Estação Liberdade, 2013.

LÖWITH, K. De Hegel à Nietzsche. São Paulo: UNESP, 2014.

O sentido da história. Lisboa: Edições 70, 1991.

MADAME DE STÃEL. Da Alemanha. São Paulo: UNESP, 2016.

MARRAMAO, G. Céu e Terra - genealogia da secularização. São Paulo: UNESP, 1997.

NIETZSCHE, F. O Anticristo. São Paulo: Companhia das Letras, 2007.

PHELAN, A. Reading Heinrich Heine. Cambridge: Cambridge University Press, 2006.

SHELLEY, M. Frankenstein ou o moderno Prometeu. Porto Alegre: LPM, 1997.

SPENER, P.J. Pia Desideria. São Bernardo do Campo: Imprensa Metodista, 1985.

SPENLÉ, J. E. O pensamento alemão - de Lutero a Nietzsche. Coimbra: Arménio Amado Editor, 1963.

\begin{tabular}{|l|l|l|l|l|}
\hline Q Rovista Qialectus & Ano 5 & n. 12 & Janeiro - Julho 2018 & p. 241-264 \\
\hline
\end{tabular}

